EPiC Series in Built Environment
Volume 2, 2021, Pages 615-625
ASC 2021. 57th Annual Associated Schools
of Construction International Conference

\title{
A Review of Studies on Sustainable Urban Regeneration
}

\author{
Ge Xuili and Vida Maliene \\ Liverpool John Moores University \\ United Kingdom
}

Over the last few decades, many countries around the world have adopted urban regeneration to solve social problems, simulate local economy, create better environmental and cultural conditions, and enhance the city's competitiveness. A holistic and critical review of the themes of these research, research methods, evaluation criteria of sustainable urban regeneration projects is needed for current and future research. Based on the journal and conference papers about sustainable urban regeneration in the SCI, EI and A\&HCI database between 1989 and 2019, this paper presents a critical review of recent studies on sustainable urban regeneration. This review focuses on the methods universally or locally employed to evaluate the sustainability of urban regeneration projects in different contexts. The key terms concerning urban regeneration, sustainability of urban regeneration, brownfield redevelopment and urban rehabilitation are clarified. The behaviours of core stakeholders and their relationship are also explored in this review. Finally, this paper discusses the future research trends for researchers to explore the field of sustainable urban regeneration.

Key Words: Urban regeneration, Sustainability, Assessment

\section{Introduction}

In the past few decades, rapid urbanization in many countries across the world has raised great challenges for urban regeneration and called for sustainable urban redevelopment. Urban regeneration, also called urban renewal, has been widely used as an effective way to stimulate economic growth, promote the economic restructuring and solve urban and social issues (Adams and Hastings, 2001; Lee and Chan, 2008). Urban regeneration is a complex process and needs to be discussed from different perspectives. Zheng et al. present a critical review of the studies on sustainable urban regeneration from 1990-2012 and his review mainly focuses on the planning and social sub-system of urban regeneration (Zheng et al., 2014). A brief review of the studies on sustainable urban regeneration in the past three decades can provide an overall understanding of the previous research that has been done on this heated topic. This paper starts with the general introduction to urban regeneration and sustainable development, then explains the criteria in selecting the journal papers, analyzes the major issues concerning sustainable urban regeneration including decision-making, public participation, sustainability assessment, heritage conservation and regeneration of brownfield and former industrial sites, etc. This paper also summarizes the major 
criteria to assess the sustainable urban regeneration based on this review. Finally, the conclusion part briefly introduces the future research trend for sustainable urban regeneration.

\section{Selection of the Journal and Conference Papers}

The key words used in this research include urban renewal, urban regeneration, urban redevelopment, and sustainable urban redevelopment/renewal/regeneration. The journal and conference papers are selected from the major databases including SCI, EI and A\&HCI database between 1989 and 2019. The major journals and proceedings include Cities, Habitat International, Sustainability, Urban Studies, Precedia Engineering, Journal of Urban Planning and Development, Sustainable Cities and Society, etc. Altogether 91 journal and conference papers are selected for this paper.

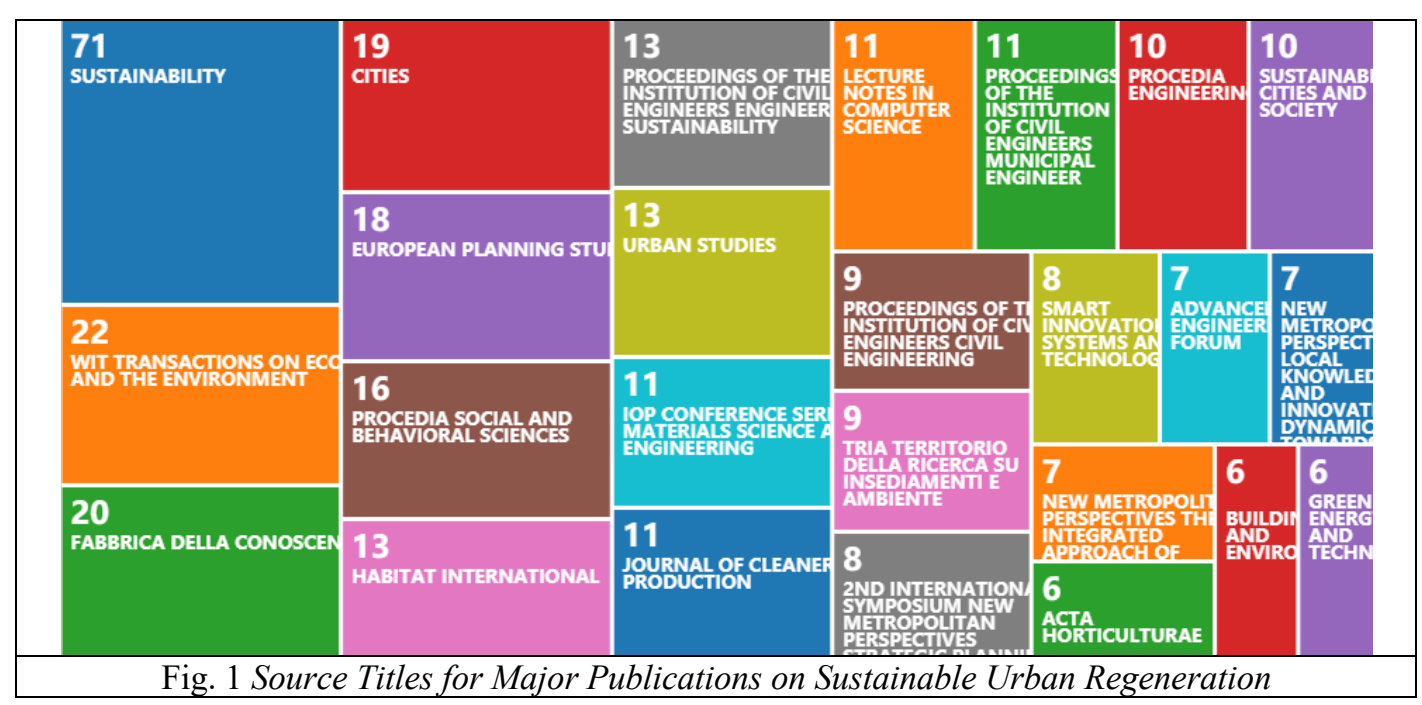

\section{Major Themes Concerning Sustainable Urban Regeneration}

Among the major publications concerning sustainable urban regeneration, there are several major groups which talk about the sustainability assessment, heritage conservation, cooperation of stakeholders, public participation, culture and heritage conservation, housing redevelopment, etc. The

\section{Heritage Conservation}

Heritage conservation has been greatly incorporated with urban regeneration and played an important role in increasing the economic and social sustainability of the regenerated area. Research has been done in built heritage, industrial heritage, tourism and many other areas. Nasser (2003) explores the conflicts among heritage protection, tourism development, and sustainable development from the symbiotic relationship between tourism and heritage areas, and proposes sustainable approaches to community and cultural heritage management and planning. What's more, some researchers also explore the issue of heritage conservation through Chinese case studies. Chiang and Deng (2017) analyze three culturally-oriented urban regeneration projects of Beijing 798 Art Zone, Shanghai M50 and Guangzhou Xinyi International Club. Niu (2018) discusses the significance of the reuse of industrial heritage in sustainable urban regeneration and provides recommendations to realize the 
culture-led sustainable urban regeneration. In addition, Lai and Lorne (2019) discuss the combination of sustainable urban regeneration and built heritage in the context of global real estate revolution. Overall, the emphasis of heritage conservation in the context of urban regeneration is closely related to the goal of sustainable development.

\section{Brownfield Land Redevelopment}

In order to solve the problems caused by deindustrialization and urbanization, brownfield land redevelopment have been utilized to increase the land supply, improve the infrastructure, and raise the economic attractiveness of cities. Pan and Song (2017) investigate the transformation of the old industrial areas, analyze the implementation and effectiveness of the urban regeneration policy, and put forward relevant suggestions for revitalizing the old industrial areas. Some researchers explore the redevelopment strategy for the regeneration of post-industrial sites. Dixon (2007) investigates the aspects of sustainable urban brownfield regeneration through two cases in Thames Gateway and Greater Manchester. Lee and Hwang (2018) establish improved urban environment through examining two cases in Seoul. An integrative methodology is devised based on a set of criteria to help to improve the planning of brownfield redevelopment (Cheng et al., 2011). Similaly, Burinskiene et al. (2017) develop a set of criteria to support the brownfield land redevelopment and sustainable urban planning. To sum up, brownfield land redevelopment is an effective way to improve the overall sustainability of urban regeneration projects.

\section{Decision-making and Public Participation}

The complexity and uncertainty of urban regeneration practice has made the decision making process more necessary. Participatory urban redevelopment can become a source of tremendous vitality and innovation for the creation of new and more just societies (United Nations Development Programme, 1993). The involvement of the public in the urban regeneration practice is an essential part of sustainable urban regeneration. Some models have been developed to help evaluate the impact of public participation and community involvement on decision-making of urban regeneration practice. Wang et al. (2016) design a two-stage PLS model to build a hierarchical linear public participation approach to comprehensively reflect the issue of public participation in sustainable urban regeneration. Zheng et al. (2017) provide a multi-scale model to support the decision-making to realize sustainable urban regeneration. Li et al. (2016) develop an evaluation model about public involvement in urban regeneration, which includes specific involvement goals, implementation objectives and evaluation indicators. What's more, through analyzing three typical urban regeneration projects in Hong Kong, Wang et al. (2014) build a framework about the main factors, which affects the decision-making process of sustainable urban regeneration practices. There is also some research about the public participation in urban redevelopment in Chinese cities. Tian and Yao (2018) explore the role of institutional change facilitating urban redevelopment in China and Zhang (2019) compares public participation in urban redevelopment in Beijing and Guangzhou and highlights the importance of policy dynamics in Chinese urban redevelopment.

\section{Expectations and Cooperation of Stakeholders}

Urban regeneration requires a set of comprehensive strategies and involves various stakeholders. Therefore, an in-depth understanding of the role and expectations of stakeholders in urban regeneration projects is an important part of achieving sustainable urban regeneration. Through questionnaires and interviews, core stakeholders of urban regeneration projects are identified and the key conflict factors of stakeholders are used to reveal the disparity of expectations among different stakeholders (Zhuang et al., 2017; Zhuang et al., 2019). Similarly, He et al. (2019) explore the diverse expectations of stakeholders in brownfield land redevelopment in China and identify 19 factors among the core stakeholders: local governments, consultants, the general public, and previous land 
users. Radulescu et al. (2016) investigate how the stakeholders of urban regeneration projects are more actively involved in the decision-making process of the renewal projects and analyze the importance of the stakeholders in specific renewal projects. If the conflicts among stakeholders are not well controlled, it will have a negative impact on the economy and society. Wang and Xiang (2017) identify 7 conflicts as critical pathways of stakeholder conflict conduction in urban regeneration. In addition to this research on stakeholders' expectations, Wang et al. (2017) choose governments, residents and developers for the key stakeholders and confirm 30 factors influencing the comprehensive benefits in urban regeneration.

\section{Assessment of Sustainable Urban Regeneration}

Fig.1 shows the proportion of papers published on sustainable urban regeneration. The searching results of Web of Science that among the 852 papers about "sustainable urban regeneration" from 1989 to 2019 , more than 500 papers were published between 2015 and 2019. It can be said that sustainable urban regeneration involves more and more attention of academia and professionals.

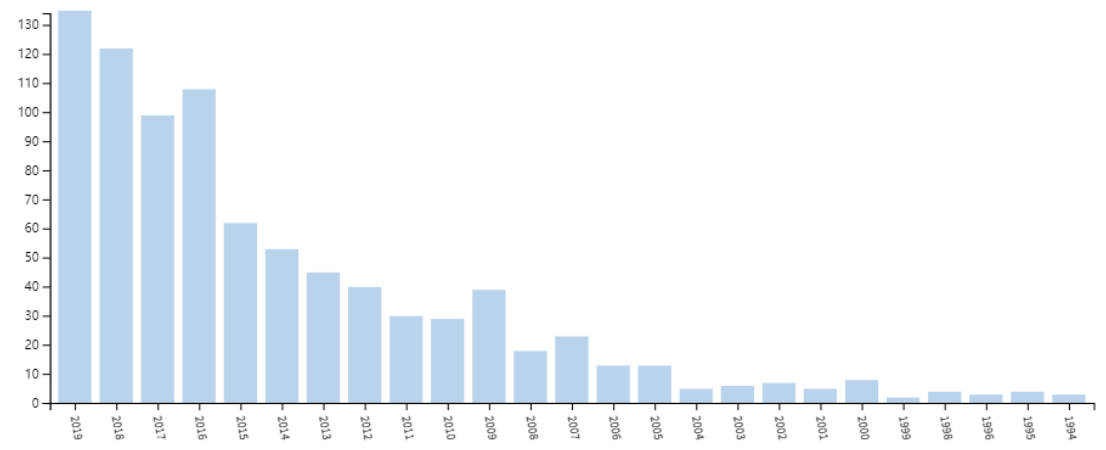

Fig. 1 Papers Published about Sustainable Urban Regeneration between 1989 and 2019

The sustainability assessment of urban regeneration can provide a guideline for key stakeholders involved in urban regeneration. At present, the assessment of the sustainability of urban regeneration is mainly based on the establishment of indicator-based assessment framework, focusing on the evaluation of economic, environmental and social sustainability of urban regeneration projects.

Environmental sustainability has always been an essential part of urban regeneration practices. The redevelopment of the derelict urban land and buildings can effectively reduce the shortage of land resource in the urban area and increase the competitiveness and appeal of urban centers (Couch \& Dennemann, 2000; Turcu, 2012a). He et al. (2011) propose a mechanism that combines urban planning and environmental assessment to meet the challenges faced by urban planning, thereby achieving the goal of urban sustainability. The indicators for measuring environmental sustainability mainly include waste disposal, recycling construction waste, increasing the use of renewable energy sources, housing conditions, improvements in infrastructure, pollution control, availability of green space and public space, conservation of built heritage, and convenience and efficiency of public transport (Wedding \& Crawford-Brown, 2007; Lee and Chan, 2008; Yildiz et al., 2017; Peng et al., 2015; Zheng, 2017). Table 1 lists the major criteria used to assess the environmental sustainability of urban regeneration practices. 
Table 1

Major Indicators for Assessing the Sustainability of Urban Regeneration (Environmental Dimension)

\begin{tabular}{|l|l|}
\hline Indicator & Sub-indicator \\
\hline Building & $\begin{array}{l}\text { reclamation of buildings, landscape design, energy efficiency of building } \\
\text { materials, energy efficiency of building design, building age, building } \\
\text { density, occupancy levels, environment-friendly construction materials, } \\
\text { inclusion building design that enhances human comfort, compatibility with } \\
\text { surrounding environment, net residential density, ratio of green space, } \\
\text { provision of open space and green space }\end{array}$ \\
\hline Waste & $\begin{array}{l}\text { Household waste separation and treatment, recycling/reuse of building } \\
\text { materials, waste generation and recycling, use of recyclable materials, waste } \\
\text { minimization }\end{array}$ \\
\hline Land use & $\begin{array}{l}\text { Reclamation of contaminated land, flexibility of future expansion, } \\
\text { adaptability of development to the changing needs, mixed land } \\
\text { use/development, efficient use of land and space }\end{array}$ \\
\hline $\begin{array}{l}\text { Energy \& } \\
\text { resources }\end{array}$ & $\begin{array}{l}\text { Energy efficient facilities, use of renewable energy, water conservation, } \\
\text { energy conservation, material conservation, district heating and cooling } \\
\text { system }\end{array}$ \\
\hline Conservation \& & $\begin{array}{l}\text { Management of buildings, facilities \& spaces, repair and rehabilitation of } \\
\text { preservation } \\
\text { propairable building structures, maintenance of buildings, facilities \& spaces, } \\
\text { prof local properties }\end{array}$ \\
\hline Transport & $\begin{array}{l}\text { Diversity of transport modes, quantity of parking facilities, quality of service } \\
\text { and facilities in public transport, public transport links/coverage, efficient and } \\
\text { safe design for drivers, efficient, convenient and safe design for pedestrians, } \\
\text { efficient and safe design for public transport, land devoted to roads, walking } \\
\text { and cycling, work and leisure travel habits }\end{array}$ \\
\hline Accessibility & $\begin{array}{l}\text { Easy access to workplace, accessibility to public facilities and services, } \\
\text { walking distance to green space, restaurant/grocery store, and amenities, } \\
\text { accessibility to green and open spaces }\end{array}$ \\
\cline { 2 - 2 } Green space/area vs built-up area \\
\cline { 2 - 3 } Increational area for different groups of citizens \\
\hline Infrastructure
\end{tabular}

Social sustainability is a complex concept and several sets of indicators have been made to assess the social sustainability of urban regeneration (Hemphill et al., 2004; Chan and Lee, 2008a; Colantonio et al., 2009). Wang (2014) explores the framework of social sustainable community in China, including three layers of individual needs, social network and community development. Weingaertner and Barber (2010) investigate the role of small businesses in sustainable urban regeneration from a socioeconomic standpoint. Chan et al. (2019) compare the level of social sustainability of two regeneration projects in Taiwan based on the social sustainability indicators developed by the Oxford Institute for Sustainable Development and through the findings from a questionnaire survey. The main indicators of social sustainability are related to social welfare, social harmony and stability, community involvement, sense of belonging in community, reduction of crime rate, conservation of local 
distinctiveness, and social interaction and integration. Table 2 lists the major criteria used to assess the social sustainability of urban regeneration practices.

Table 2

Major Indicators for Assessing the Sustainability of Urban Regeneration (Social Dimension)

\begin{tabular}{|l|l|}
\hline Indicator & Sub-indicator \\
\hline Demographics & $\begin{array}{l}\text { Diversity of ages, population growth, net population density, marriage } \\
\text { situation, income mix, education degree, tenure mix }\end{array}$ \\
\hline $\begin{array}{l}\text { Public facilities } \\
\text { \& services }\end{array}$ & $\begin{array}{l}\text { Diversity of public facilities, provision of public facilities and services, public } \\
\text { facilities for different groups of people, green and open space for various } \\
\text { activities }\end{array}$ \\
\hline $\begin{array}{l}\text { Safety \& } \\
\text { security }\end{array}$ & $\begin{array}{l}\text { Security by design, safety of public places, reduction in crime rates, response } \\
\text { to fire or emergency }\end{array}$ \\
\hline Social capital & $\begin{array}{l}\text { Social inclusion, social integration, preserving social network, sense of } \\
\text { community/belonging }\end{array}$ \\
\hline $\begin{array}{l}\text { Heritage } \\
\text { conservation }\end{array}$ & $\begin{array}{l}\text { Conservation of built heritage, preservation of historic buildings, preservation } \\
\text { of local distinctiveness, preservation of local culture, }\end{array}$ \\
\hline $\begin{array}{l}\text { Community \& } \\
\text { well-being }\end{array}$ & $\begin{array}{l}\text { Community involvement, citizen participation in local urban design, residents' } \\
\text { satisfaction surrounding environment, residential floor area per capita, } \\
\text { residents' satisfaction with their own home }\end{array}$ \\
\hline
\end{tabular}

The indicators of economic sustainability mainly focus on local employment, adaptability of land development, types and availability of training programs, diversity of new business activities, local economic growth and affordability of housing (Hemphill, 2004; Wedding and Crawford-Brown, 2007; Chan and Lee, 2008b; Turcu, 2012; Laprise et al., 2015). Overall, indicator-based assessment framework is an efficient way to evaluate the performance of urban regeneration practices (Chan and Lee, 2008a; Colantonio et al., 2009; Deng, 2012; Turcu, 2012a; Laprise et al., 2015; Balaban, 2015). Table 3 lists the major criteria used to assess the economic sustainability of urban regeneration practices.

Table 3

Major Indicators for Assessing the Sustainability of Urban Regeneration (Economic Dimension)

\begin{tabular}{|l|l|}
\hline Indicator & Sub-indicator \\
\hline Job & $\begin{array}{l}\text { Employability/Availability of local employment, net number of jobs created, quality } \\
\text { of jobs created, training programs provided, increase of new employees }\end{array}$ \\
\hline Income & Average yearly salary, increase in income, disposable personal income \\
\hline Business & $\begin{array}{l}\text { Diversity of business activities and services, level of local business activity, } \\
\text { restructuring local business services and activities, promoting the development of } \\
\text { small businesses }\end{array}$ \\
\hline Housing & $\begin{array}{l}\text { Housing affordability, provision of accommodation for different income groups, } \\
\text { increase in surrounding property values, rent to income ratio }\end{array}$ \\
\hline
\end{tabular}

\section{Culture-led Urban Regeneration}


Creative industry has played a significant role in stimulating economic growth, solving social issues, and facilitating urban transformation \& economic recovery during the redevelopment of former industrial sites (Evans, 2005; Moldoveanu \& Franc, 2014). The culture-led urban regeneration strategies have been widely employed to create positive urban landscapes, boost urban economic growth and enhance the cities' competitive position (Bassett, 1993; Bianchini and Parkinson, 1993; Garcia, 2004; Evans, 2005). Miles (2005) believes that successful culture-led urban regeneration projects should engage with people's sense of belongings in a place. Likewise, Bailey et al. (2004) argue that linking local cultural projects with civic identities can help local communities and enhance local distinctiveness. Kagan et al. (2018) discuss the regeneration cases in Hamburg and Hanover and compare the relationship between culture and policies for sustainable urban development. Chen and Yang (2018) analyze the data in Ping-Jiang by using demographic analysis and regression model, emphasizing the impact of conservation planning on local population and residential mobility on sustainable urban regeneration. As Fig. 3 indicates, the searching results on "culture-led urban regeneration" in Web of Science shows that creative cities, policy, strategies and gentrification are the main topics for carrying out culture-led urban regeneration.

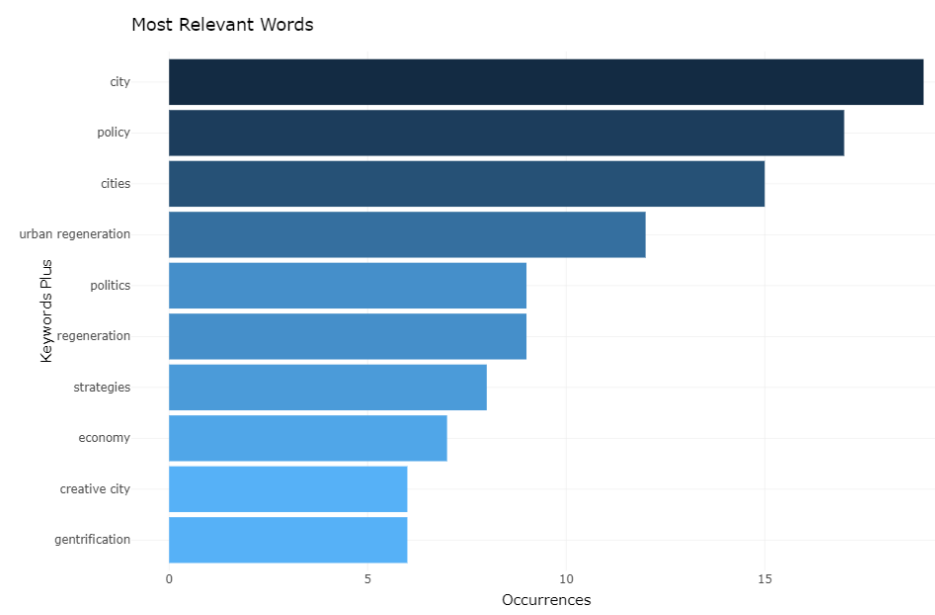

Fig. 3 Most Relevant Words in Papers about Culture-led Urban Regeneration

\section{Housing and Community Development}

Generally speaking, any form of urban regeneration can increase the sustainable development through recycling the building materials and improving the living conditions of the area. The redevelopment of residential areas in the city centre can increase the land supply for economic restructuring and urban development. The planning and development of real estate industry is closely related to the sustainable development of the city. By analyzing the relevant policies of city redevelopment, Bromley et al (2005) reveal the contradiction of current policies and emphasize the influence of residential areas in city centre on sustainable urban regeneration based on the household survey in two cities in the UK. Turcu (2012b) summarizes the sustainable urban regeneration experience of three neighborhoods in Salford, Newcastle and Merseyside by interviewing about 130 residents and 60 officials and stakeholders. Sustainable urban regeneration requires that more affordable housing should be provided to attract people to move back to the city center area. Sustainable housing regeneration considers the location, construction, design, maintenance, community and neighborhood development. Winston (2009) assesses the potential of eco-neighborhoods to sustainable regeneration 
based on the definition of sustainable development of the World Commission on Sustainable Development.

Lloyd (2002) and Murdoch (2005) discuss the positive role of community development in urban regeneration by examining the particular community development cases in Scotland. Perez et al. (2018) assess the existing neighborhoods from six sustainability objectives: ensuring the viability of the urban regeneration project, providing housing to a large number of inhabitants, balancing the supply of jobs of jobs and housing, saving energy resources, upgrading local environments and fostering a balance between density and urban quality. Deakin and Allwinkle (2007) analyze the relationship between urban regeneration and sustainable communities and recognize the critical role of networks, innovation and creativity play in building sustainable communities. Overall, reasonable planning and sustainable community development play a critical role in improving the sustainability of urban regeneration projects.

\section{Conclusion}

Based on the literature research, this paper reviews the major topics concerning sustainable urban regeneration, including heritage conservation, brownfield land redevelopment, decision-making and public participation, expectations and cooperation of stakeholders, assessment of sustainable urban regeneration, housing and community development, social and environmental sustainability. Sustainable urban regeneration has gradually become the indispensable part of urban regeneration practices. In this paper, the main indicators of sustainability assessment of urban regeneration have been summarized. For the sustainable development of urban regeneration, more indicator-based frameworks have been built and will be adapted in different countries and areas according to specific situations.

For future research on sustainable urban regeneration, more studies might be done on combining the urban regeneration with the establishment of smart city, eco city, liveable city, resilient city and knowledge city. Urban regeneration is a comprehensive project which involves various subjects and the cooperation of more stakeholders can help achieve a win-win situation. In future, the participation of different stakeholders, the establishment of local, national and international rules and policies on sustainable urban regeneration would be the main topics for studying sustainable urban regeneration.

\section{Acknowledgements}

This article is sponsored by The Educational Department of Liaoning Province. Project: On the Establishment of the Framework to Assess the Sustainability of Urban Regeneration --- A Case Study of Liaoning Province. Project number: J202076

\section{References}

Adams, D. and Hastings, E.M. (2001) Urban Renewal in Hong Kong: Transition from Development Corporation to Renewal Authority. Land Use Policy, 18, pp. 245-258.

Bailey, C., Miles, S. and Stark, P. (2004) Culture-led urban regeneration and the revitalization of rooted identities in Newcastle, Gateshead and the North East of England, International Journal of Cultural Policy, 10(1), pp. 47-65.

Balaban, O. (2015) The Use of Indicators to Assess Urban Regeneration Performance for Climatefriendly Urban Development: The Case of Yokohama Minato Mirai 21. Spatial Planning and Sustainable Development. Eds. Kawakami, M. et al., pp. 91-115. 
Bassett, K. (1993) Urban cultural strategies and urban regeneration: a case study and critique, Environment and Planning A, 25(2), pp. 1773-1788.

Bianchini, F. and Parkinson, M. (Eds) (1993) Cultural Policy and Urban Regeneration: The West European Experience. Manchester: Manchester University Press.

Bromley, R. et al. (2005) City Centre Regeneration through Residential Development: Contributing to Sustainability. Urban Studies, 42 (13), pp. 2407-2429.

Burinskiene, M. et al., (2017) Evaluating the Significance of Criteria Contributing to Decision-Making on Brownfield Land Redevelopment Strategies in Urban Areas. Sustainability, 9, 759.

Chan, H. et al. (2019) Social Sustainability of Urban Regeneration led by industrial land redevelopment in Taiwan. European Planning Studies, 27: 7, pp. 245-1269.

Chan E.H.W, Lee G.K.L. (2008a) Critical factors for improving social sustainability of urban renewal projects. Social Indicator Research, Vol. 85. pp. 243-256.

Chan E.H.W, Lee G.K.L. (2008b) Contribution of urban design to economic sustainability of urban renewal projects in Hong Kong. Sustainable Development, 16 (6), pp, 353-364.

Chen, Y. and Yang, J. (2018) The Chinese Socio-Cultural Sustainability Approach: The Impact of Conservation Planning on Local Population and Residential Mobility. Sustainability. 10 (11), 4195.

Cheng, F. et. al. (2011) An Integrative methodology to improve brownfield redevelopment planning in Chinese cities: A Case Study of Futian, Shenzhen. Computers, Environment and Urban Systems, 35, pp. 388-398.

Chiang, Y. and Deng, Y. (2017) City Gate as Key towards Sustainable Urban Redevelopment: A Case Study of ancient Gungnae City within the Modern City of Ji' an. Habitat International, 67, pp. 1-12.

Colantonio, A. and Dixon, T. (2009) Measuring Socially Sustainable Urban Regeneration in Europe. Oxford Institute for Sustainable Development (OISD). Oxford Brookes University, Oxford.

Couch, C. and Dennemann, A. (2000) Urban regeneration and sustainable development in Britain. The example of the Liverpool Ropewalks Partnership. Cities, 17 (2). pp. 137-147

Deakin, M. and Allwinkle, S. (2007) Urban Regeneration and Sustainable Communities: The Role of Networks, Innovation, and Creativity in Building Successful Partnerships. Journal of Urban Technology, 14: 1, pp. 77-91.

Deng, KQ. (2012) The Sustainability Assessment of Different models for urban renewal - A Case of Guangzhou. PhD dissertation. Huazhong University of Science \& Technology.

Dixon, T. (2007) The Property Development Industry and Sustainable Urban Brownfield Regeneration in England: An Analysis of Case Studies in Thames Gateway and Greater Manchester. Urban Studies, 44: 12, pp. 2379-2400.

Evans, G. (2005) Measure for Measure: Evaluating the Evidence of Culture's Contribution to Regeneration. Urban Studies. Vol. 42. pp. 959-983.

García, B. (2004) Urban regeneration, arts programming and major events, International Journal of Cultural Policy, 10(1), pp. 103-118.

He, F. et al. (2019) Exploring the Diverse Expectations of Stakeholders in Industrial Land Redevelopment Projects in China: The Case of Shanghai. Sustainability, 11, 4744.

He, J. et al. (2011) Framework for integration of urban planning, strategic environmental assessment and ecological planning for urban sustainability within the context of China. Environmental Impact Assessment Review, 31 (6), pp. 549-560.

Hemphill L., Berry J, McGreal S. (2004) An indicator-based approach to measuring sustainable regeneration performance: part 1. Conceptual foundations and methodical framework. Urban Studies 41 (4). pp. 725-755.

Kagan, S. et al. (2018) Culture in Sustainable Urban Development: Practices and Polices for Spaces of Possibility and Institutional Innovations. City, Culture and Society, 13, pp.32-45.

Lai, L.W.C. and Lorne, F.T. (2019) Sustainable Urban Renewal and Built Heritage Conservation in a Global Real Estate Revolution. Sustainability, 11 (850). 
Laprise, M., Lufkin, S. and Rey, E. (2015) An Indicator System for the Assessment of Sustainability Integrated into the Project Dynamics of Regeneration of Disused Urban Areas. Building and Environment, 86, pp. 29-38.

Lee G.K.L. and Chan E.H.W. (2008) Factors Affecting Urban Renewal in High-density city: Case Study of Hong Kong. Urban Plann. Dev. 134, pp. 140-148.

Lee G.K.L. and Chan E.H.W. (2010) Evaluation of the urban renewal projects in social dimensions. Property Management, 28 (4). pp. 257-269.

Lee, I.L. and Hwang, S. (2018) Urban Entertainment Center (UEC) as a Redevelopment Strategy for Large-Scale Post-Industrial Sites in Seoul: Between Public Policy and Privatization of Planning. Sustainability, 10:10, 1-17.

Li, L. et al. (2016) Evaluating the Performance of Public Involvement for Sustainable Urban Regeneration. International Conference on Sustainable Design, Engineering and Construction. Procedia Engineering, 145, pp. 1493-1500.

Lloyd, M. (2002) Urban Regeneration and Community Development in Scotland: Converging Agendas for Action. Sustainable Development, 10, pp. 147-154.

Miles, S. (2005) 'Our Tyne': iconic regeneration and the revitalisation of identity in NewcastleGateshead, Urban Studies, 42(5/6), pp. 913-926.

Moldoveanu, M. \& Franc, V. (2014) Urban regeneration and more opportunities for artistic expression and cultural consumption. Procedia Economics and Finance, Vol. 8. pp. 490 - 496.

Murdoch, S. (2005) Community Development and Urban Regeneration. Community Development Journal, 40 (4), pp. 439-446.

Nasser, N. (2003) Planning for Urban Heritage Places: Reconciling conservation, Tourism, and Sustainable Development. Journal of Planning Literature, 17 (4), pp. 467-479.

Niu, S. (2018) Sustainability Issues in the Industrial Heritage adaptive Reuse: Rethinking Culture-led Urban Regeneration through Chinese Case Studies. Journal of Housing and the Built Environment, 33, pp. 501-518.

Pan, M. and Song, H. (2017) Transformation and Upgrading of Old Industrial Zones on Collective Land: Empirical Study on Revitalization in Nashan. Habitat International, 65, pp. 1-12.

Peng, Y. et al. (2015) An Alternative Model for Measuring the Sustainability of Urban Regeneration: The Way Forward. Journal of Cleaner Production, no. 109, pp. 76-83.

Perez, M. Laprise, M. and Rey, E. (2018) Fostering Sustainable Urban Renewal at the Neighborhood Scale with a Spatial Decision Support System. Sustainable Cities and Society, 38, pp. 440-451.

Radulescu, C.M. et al. (2016) Management of Stakeholders in Urban Regeneration Projects. Case Study: Baia-Mare, Transylvania. Sustainability, 8, 238.

Tian, L. and Yao, Z. (2018) From State-dominant to Bottom-up Redevelopment: Can Institutional Change Facilitate Urban and Rural Redevelopment in China. Cities, 76, pp. 72-83.

Turcu, C. (2012a) Re-thinking Sustainability Indicators: Local Perspectives of Urban Sustainability. Journal of Environmental Planning and Management, 56 (5), pp. 695-719.

Turcu, C. (2012b) Local Experiences of Urban Sustainability: Researching Housing Market Renewal Interventions in three English neighborhoods. Progress in Planning, 78, pp. 101-150.

United Nations Development Program (UNDP). (1993) New York: Oxford University Press.

Wang, A. et al. (2016) Group Decision Making Model of Urban Renewal Based on Sustainable Development: Public Participation Perspective. Procedia Engineering, 145, pp. 1509-1517.

Wang, H. et al. (2014) A Framework of decision-making factors and supporting information for facilitating sustainable site planning in urban renewal projects. Cities, 40, pp.44-55.

Wang, Y. (2014) The Framework of Social Sustainability for Chinese Communities: Revelation from Western Experiences. International Review for Spatial Planning and Sustainable Development, 2 (3), pp. 4-17. 
Wang, Y. and Xiang, P. (2019) Investigating the Conduction Path of Stakeholder Conflict of Urban Regeneration Sustainability in China: the Application of Social-Based Solutions. Sustainability, 11, 5271.

Wang, Y. et al. (2017) Fuzzy Evaluation of Comprehensive Benefit in Urban Renewal Based on the Perspective of Core Stakeholders. Habitat International, 66, pp. 163-170.

Wedding, G.C. and Grawford-Brown, D. (2007) Measuring Site-level Success in Brownfield Redevelopments: A Focus on Sustainability and Green Building. Journal of Environmental Management, no. 85, pp. 483-495.

Weingaertner, C. and Barber, A. (2010) Urban Regeneration and Socio-economic Sustainability: A Role for Established Small Food Outlets. European Planning Studies, 18:10, 1653-1674.

Winston, N. (2009) Urban Regeneration for Sustainable Development: The Role of Sustainable Housing? European Planning Studies, 17: 12, pp. 1781-1796.

Yildiz, S., Kivrak, S. and Arslan, G. (2017) Factors Affecting Environmental Sustainability of Urban Renewal Projects. Civil Engineering and Environmental Systems, 34:3-4, pp. 264-277.

Zhang, L. (2019) Heterogeneity of Public Participation in Urban Redevelopment in Chinese Cities: Beijing versus Guangzhou. Urban Studies. 1-17.

Zheng, H.W. et al. (2017) Neighborhood Sustainability in Urban Renewal: An Assessment Framework. Environment and Planning B: Urban Analytics and City Science, 44 (5), pp. 903-924.

Zheng, W. et al. (2014) A Review of Recent Studies on Sustainable Urban Renewal. Habitat International, 41, pp. 272-279.

Zheng, W. et. al. (2017) Decision Support for Sustainable Urban Renewal: A Multi-scale Model. Land Use Policy, 69, pp. 361-371.

Zhuang, T. et al. (2017) Sustainability. Stakeholders' Expectations in Urban Renewal Projects in China: A Key Step towards Sustainability. Sustainability, 9, 1640.

Zhuang, T. et al. (2019) The Role of Stakeholders and Their Participation Network in Decision-making of Urban Renewal in China: The Case of Chongqing. Cities, 92, pp. 47-58. 